\title{
Potential Social Web Sites Addiction Motives among University Students
}

\author{
Hanaa A. Hameed Radwan ${ }^{1}$, Sorayia R. Abd El Fattah ${ }^{2}$, Maaly I. El Malky ${ }^{3}$, \\ ${ }^{4}$ Gehan A. Abed, ${ }^{5}$ Lamiaa $H$.Eita, \\ ${ }^{23}$ Assistant professor of Psychiatric, Mental Health Nursing \\ ${ }^{45}$ Lecturer of Psychiatric, Mental Health Nursing, Faculty of Nursing, Menoufia University
}

\begin{abstract}
Social websites are excessively used today among university students. Many students use it for different reasons which put them at risk for social websites addiction. The purpose of the study was to assess the potential social websites addiction motives among university students. Design: A descriptive correlational research design was utilized. The setting was first-year students at the faculty of art and faculty of nursing. Sample: A purposive sample of 14 ' students was selected from the above mention setting who have scores of 50 to 79 on social networking sites addiction scale (high-risk groups).Two instruments were used for data collection: instrument one contained an interview questionnaire composed of two parts about socio-demographic characteristics and social websites use data. Instrument two included two parts; part one was Internet use motives scale and part two included social networking addiction scale. The results revealed that the most common motives level were escaped from stress, social integration, and lack of assertiveness $(77.14 \%, 72.86 \%, 64.28 \%$, respectively).There was an increase in the mean score of sexual behavior as a motive for social websites use among males students than females students while there was an increase in the mean score of control as a motive for social websites use among females students than males students. There was a highly statistically significant positive correlation between potential social websites addiction and both of a lack of assertiveness, escape from stress and total motive for social websites use. It was concluded that the highest motives level for social websites use were escape from stress, social integration and a lack of assertiveness respectively. Thus, it was recommended that counseling program are needed to help the university students to control use social web sites and prevent falling into addiction
\end{abstract}

Key words: Motives, potential social websites addiction

\section{Introduction}

The world is changing over the time as a result of advancements in science and technology, with one such advancement being in the scope of social networking. Social networking sites have gained popularity in recent years (Adnan Shahzad, Husain, Iqbal and Nawaz, 2015). For many, the use of these social media platforms have become the daily routine particularly for university students which it has become an

have shared similar interests, activities and real-life acquaintances or even with total strangers (Karahanna, Xuand, and Zhang, 2015).

Despite the benefits of social websites, it also brings threats to the adolescence. Spending an excessive amount of time on social networking sites might lead to severe negative effects of various activities in people's life like school, work and face-to-face interactions and growing concerns of addiction related to social networking behavior (Sevilla, 2012).

Nature of people addicted to social networking sites have an obsession or mental preoccupation of many social website activities, as a result tends to neglect alternative aspects of their social functioning like real life relationship with family and friend. In addition, experience withdrawal symptoms once stop using social websites that at least partially resemble the ones seen during alcohol, drug abstinence syndrome (Pantic, 2014). 
Potential Social Web Sites Addiction Motives among University Students

Students use social networking sites to gratify their needs for entertainment, social interaction, a romantic relationship, information seeking, information about social events, selfpresentation, and client addiction. Accordingly, the psychiatric nurse will help high-risk clients to confront these phenomena by learning new skills to strain against these phenomena (King, Delfabbro, and Griffiths, 2012). The more nurses learn about reasons behind visiting social sites, the better they are able to regulate social websites behavior (Makashvili, Ujmajuridze, Amirejibi, Kotetishvili, and Barbakadze, 2013). Therefore, this study aimed to assess the potential social websites addiction motives among university students.

\section{Purpose}

The purpose of the study is to assess potential social websites addiction motives among university students

\section{Research question}

- What are the motives of social websites use among potential social websites addiction of university students?

- Is there a difference between genders regarding social websites motives?

- Is there a correlation between motives of social websites use and potential social web sites addiction among university students?

Sample size has been calculated using the following equation: $\mathrm{n}=(\mathrm{z} 2 \times \mathrm{p} \times$ q)/D2 at CI $95 \%$ and power $80 \%$, level of confidence (error $=5 \%$ ).

\section{Inclusion criteria:}

1. High risk groups who have scores of 50 to 79 on social networking sites addiction scale.

2. Age between 17-20 years old.

\section{Exclusion criteria:}

1.Students who have scored less than 49 or over 80 on social networking sites addiction scale
2. Students who disagree to participate in the study

\section{Instruments: Two instruments were} used for data collection

- Instrument one: it involved a structure interview questionnaire. It was developed by the researcher based on the scientific reviewing literature and includes two parts. The first part was designed to assess a social-demographic characteristic of studied students such as age, gender, religions, faculty type, and residence. The second part was designed to assess social networking sites use data such as duration, the number of hours of social sites uses per/day and most common sites used

Instrument two (part one): it involved Internet use motives. It was developed by Shaheen, (2010).

Instrument two (part two): Social networking site addiction Likert scale. It was developed by Rabie, (2003). It was used to measure potential social website addiction. It consisted of twenty items. It included a six- point likert scale include: Does not apply (0), Rarely (1) Occasionally (2) Frequently (3) Often (4) Always (5). Scores ranged from 20-49 points were referred to an average online user. Scores which ranged from 50-79 points referred to potential social websites addiction, Scores from 80-100 points meant that the students became addicted to the social websites.

Validity of instruments: Research instrument were submitted to a jury of five experts in psychiatric nursing and medicine (Three professors and one assistant professor of psychiatric mental health nursing, one assistant professor of psychiatric medicine), to check the relevance, coverage of the content and clarity of the questions. 
Reliability of the instruments was assessed using Cronbach's alpha coefficients internal consistency of escape from stress, fun, and entertainment, social integration, control, personal integration, lack of assertiveness, sex behavior, self. All of the authorized personnel provided the needed information about the purpose and the importance of the study-The researcher started data collection by introducing himself to the participant and explaining the purpose of the study. Students were arranged in groups (each group contained 36 students).The researcher explained to each group how to fill the data collection instruments.

The researcher collected the data during the morning at one day/week for each faculty. Students lasted for 20-30 minutes to fill each instrument. The process of data collection took a period of three months from September 2016 to December 2016.

\section{Statistical analysis}

The collected data were organized, tabulated and statistically analyzed using SPSS version 20.0. Graphics were done using excel program. Data were presented using descriptive statistics in the form of frequencies and percentages for qualitative variables. For comparison between gender for social websites motives among studied students Fisher exact test was used, for correlation between social websites motives and potential social websites addiction represented that the more than two-thirds (72.86) and more than half $(55 \%)$ of the studied students respectively had a moderate level of social integration and gaining information motives.

Figure (5): Frequency distribution of students according to their level of sexual behavior motives. This figure clarified that $(6.43 \%)$ of the studied students were had a moderate level of sexual behavior motive while $(2.14 \%)$ were had a high level of sexual behavior motives.

Figure (6): Frequency distribution of students according to their total score of social websites motive. This figure reflects that nearly one-third $(31.43 \%)$ of the studied students had a moderate level of a total score of social websites motive

Table (1): Motivations for potential social websites addiction motives among males and females students. This table showed that there was an increase in the mean score of sexual behavior and the total score motives for social websites use among males students than females students with a highly statistically significant difference at $\mathrm{p}$-value $<0.001^{* *}$ and $\mathrm{p}$ value $<0.05 *$ respectively. While there was an increase of the mean score of control motive for social integral part of their social life for others. These platforms don't seem to be so interesting or they have a pleasurable feeling in utilizing them for a purpose, such as for searching information. Social websites act as tools for cooperative communication, enabling information sharing between users/ members of a defined virtual world (Ting- Peng, and Efraim, 2012).

Social websites provide a mean to construct social relations and linkages among people who gossip about their friends and acquaintances, voyeurism and expressing their identity, obtaining, sharing problems with others and filling their free time (Smock, Ellison Lampe and Wohn, 2011). Other motives for using social networking sites are relaxation, meeting other people, habit, professional development and following new trends, escapism, academic activities and peer pressure (Froget, Baghestan, and Asfaranjan, 2013).

In this respect the students who use the websites frequently (3-5 hours/day) for pleasure seeking 


\section{Potential Social Web Sites Addiction Motives among University Students}

activity like chat or communication, new, entertainment and social webs sites purposes have significantly higher social websites addiction tendency than the students who use it for less than 3 hours/day or for scientific purposes (Mihara, et al.,2016). In other words, people who spent excessive time on social websites (except studying or gaining information) reported higher addictive tendencies

Cheung, $\mathrm{Ku}$, and Hung 2013).

The psychiatric nurse has an important role in the assessment, diagnosis, and prevention of social websites addiction, which focus on the determining the motives that trigger addictive feelings as well as explore the origins of the problem or determine the underlying reason for Theoretical and operational definitions of potential social websites addiction motives Motives are theoretically defined as the impetus that gives purpose or direction to human behavior or forces that drive human behavior that push it toward a specific goal or action (Lin, 2007). Potential social websites addiction motives in the present study are the lack of assertiveness, escape from stress, control, personal integration, selfesteem, social integration, fun, and entertainment, gain information and sexual behavior. Students had potential risk if they achieved scores between 50-79 in the internet use motives questionnaire that was developed by Shaheen, (2010)

\section{Methods}

\section{1-Research Design:}

A descriptive correlational research design was used

\section{2-Research Setting:}

This study was done in the faculty of art and faculty of nursing in Menoufia University. One year was selected randomly, namely, the first grade of both faculties

\section{3-Sampling:}

A purposive sample of 14. students who have scores of 50 to 79 on social networking sites addiction scale was selected from the previously mentioned setting.

It was used to measure the motives for excessive use of social networking sites. It was modified by the researcher based on Soh, Hong, Charlton, (2013), Omar and Subramanian, (2013), Abdel-Sadek, (2013). It consisted of 61 items. These items covered eight domains: escape from stress ( 7 items), fun and recreation (5 items), social integration (8 items), Lack of assertiveness (15 items), personal integration (7items), gain information (6 items), control (5 items), sexual motives( 3 item)and self-esteem (5 items)

Scoring system for each item.

\begin{tabular}{|l|l|}
\hline Score & Scoring items \\
\hline 4 & Always \\
\hline 3 & Sometimes \\
\hline 2 & Rarely \\
\hline 1 & Never \\
\hline
\end{tabular}

A scoring system of eight domains is stated as the following

\begin{tabular}{|l|c|c|c|c|}
\hline \multirow{2}{*}{$\begin{array}{l}\text { Motive for } \\
\text { social } \\
\text { websites use }\end{array}$} & \multicolumn{4}{|c|}{ Scoring Item } \\
\cline { 2 - 5 } & $\begin{array}{c}\text { Nor } \\
\text { mal }\end{array}$ & \multicolumn{4}{|c|}{ Mild } & \multicolumn{1}{|c|}{$\begin{array}{c}\text { Moder } \\
\text { ate }\end{array}$} & High \\
\cline { 2 - 5 } & \multicolumn{4}{|c|}{ Score } \\
\hline $\begin{array}{l}\text { Lack of } \\
\text { assertiveness }\end{array}$ & $\begin{array}{c}15- \\
22\end{array}$ & $23-37$ & $38-52$ & $53-60$ \\
\hline $\begin{array}{l}\text { Escape from } \\
\text { stress }\end{array}$ & $7-10$ & $11-17$ & $18-23$ & $24-28$ \\
\hline Control & $5-7$ & $8-12$ & $13-17$ & $18-20$ \\
\hline $\begin{array}{l}\text { Personal } \\
\text { integration }\end{array}$ & $7-10$ & $11-17$ & $18-23$ & $24-28$ \\
\hline Self - esteem & $5-7$ & $8-12$ & $13-17$ & $18-20$ \\
\hline $\begin{array}{l}\text { Fun and } \\
\text { entertainment }\end{array}$ & $5-7$ & $8-12$ & $13-17$ & $18-20$ \\
\hline $\begin{array}{l}\text { Gain } \\
\text { information }\end{array}$ & $6-9$ & $10-15$ & $16-21$ & $22-24$ \\
\hline $\begin{array}{l}\text { Social } \\
\text { integration }\end{array}$ & $8-12$ & $13-20$ & $21-28$ & $29-32$ \\
\hline $\begin{array}{l}\text { Sexual } \\
\text { behavior }\end{array}$ & $3-4$ & $5-6$ & $7-9$ & $10-12$ \\
\hline
\end{tabular}

- Instrument two (part two): Social networking site addiction Likert scale. It was developed by Rabie, (2003). It was 
Potential Social Web Sites Addiction Motives among University Students

used to measure potential social website addiction. It consisted of twenty items. It included a six- point likert scale include: Does not apply (0), Rarely (1) Occasionally (2) Frequently (3) Often (4) Always (5). Scores ranged from 2049 points were referred to an average online user. Scores which ranged from 50-79 points referred to potential social websites addiction, Scores from 80-100 points meant that the students became addicted to the social websites.

Validity of instruments: Research instrument were submitted to a jury of five experts in psychiatric nursing and medicine (Three professors and one assistant professor of psychiatric mental health nursing, one assistant professor of psychiatric medicine), to check the relevance, coverage of the content and clarity of the questions.

Reliability of the instruments was assessed using Cronbach's alpha coefficients internal consistency of escape from stress, fun, and entertainment, social integration, control, personal integration, lack of assertiveness, sex behavior, self-esteem and gain information $(0.82,0.78,0.85$, 0.79 , $\quad 0.77,0.86,0.81,0.83,86.65)$ respectively. Also, instrument three was reliable at .77 .

The pilot study was carried out on $10 \%$ of the total sample (20 students) after instruments were developed and before starting the data collection to test the applicability, feasibility, and clarity of the tools and to estimate the needed time to fill the tool. After obtaining the result of the pilot study, the necessary modifications of tools as (modified questions) were done then the final format was developed under the guidance of supervisors. Those students were excluded from the actual study.

Ethical considerations: an oral acceptance was taken from each student in the study after explaining the purpose and the importance of the study. The study was voluntary, anonymous, and confidentiality of students would respect. All students had the full right to refuse to participate in the study and withdraw at any time.

\section{Procedure of data collection}

- Before data collection, an official letter was addressed about the purpose of study from the dean of the faculty of nursing to the dean of the faculty of art, Menoufia University and head of the department of firstyear students in the faculty of nursing.

- All of the authorized personnel provided the needed information about the purpose and the importance of the study.

- The researcher started data collection by introducing himself to the participant and explaining the purpose of the study.

- Students were arranged in groups (each group contained 36 students). The researcher explained to each group how to fill the data collection instruments.

- The researcher collected the data during the morning at one day/week for each faculty.

- Students lasted for 20-30 minutes to fill each instrument. The process of data collection took a period of three months from September 2016 to December 2016.

\section{Statistical analysis}

The collected data were organized, tabulated and statistically analyzed using SPSS version 20.0. Graphics were done using excel program. Data were presented using descriptive statistics in the form of frequencies and percentages for qualitative variables. For comparison between genders for social websites motives among studied students Fisher exact test was used, for correlation between social websites motives and potential social websites addiction

Pearson's correlation coefficient test was used. The level of significance was set at a highly significant level if P- 


\section{Potential Social Web Sites Addiction Motives among University Students}

value $<0.001$ and significant level if $\mathrm{P}$ value $<0.05$ while $\mathrm{P}$-value $>0.05$ was not-significant.

\section{Results:}

Figure (1): Frequency distribution of students according to their level of lack of assertiveness and escape from stress. This figure showed that two-thirds of the studied students $(64.28 \%, 77.14$ \%respectively) had a moderate level of lack of assertiveness and escape from stress motives.

Figure (2): Frequency distribution of students according to their level of personal integration and control motives. This figure revealed that nearly half (44.28) and nearly quarter $(19.29 \%)$ of studied students respectively had a moderate level of control and personal integration motives.

Figure (3): Frequency distribution of students according to their level of selfesteem and fun and entertainment motives. This figure showed that more than one-third of the studied students (40\%, 47.14\% respectively) had a moderate level of self-esteem and fun and entertainment motives.

Figure (4): Frequency distribution of students according to their level of social integration and gaining information motives. This figure represented that the more than twothirds (72.86) and more than half (55\%) of the studied students respectively had a moderate level of social integration and gaining information motives.

Figure (5): Frequency distribution of students according to their level of sexual behavior motives. This figure clarified that $(6.43 \%)$ of the studied students were had a moderate level of sexual behavior motive while $(2.14 \%)$ were had a high level of sexual behavior motives

Figure (6): Frequency distribution of students according to their total score of social websites motive. This figure reflects that nearly one-third $(31.43 \%)$ of the studied students had a moderate level of a total score of social websites motive

Table (1): Motivations for potential social websites addiction motives among males and females students. This table showed that there was an increase in the mean score of sexual behavior and the total score motives for social websites use among males students than females students with a highly statistically significant difference at $\mathrm{p}$ value $<0.001^{* *}$ and $\mathrm{p}$-value $<0.05^{*}$ respectively. While there was an increase of the mean score of control motive for social

Websites use among female students than male students with a highly statistically significant difference at $\mathrm{p}$ value $<0.001 * *$

Table (2): Correlation between motives for social websites use and potential social websites addiction among studied students. This table showed that there was a positive highly statistically significant correlation between potential social websites addiction and both of lack of assertiveness, escape from stress and the total score of motive for social websites use. 


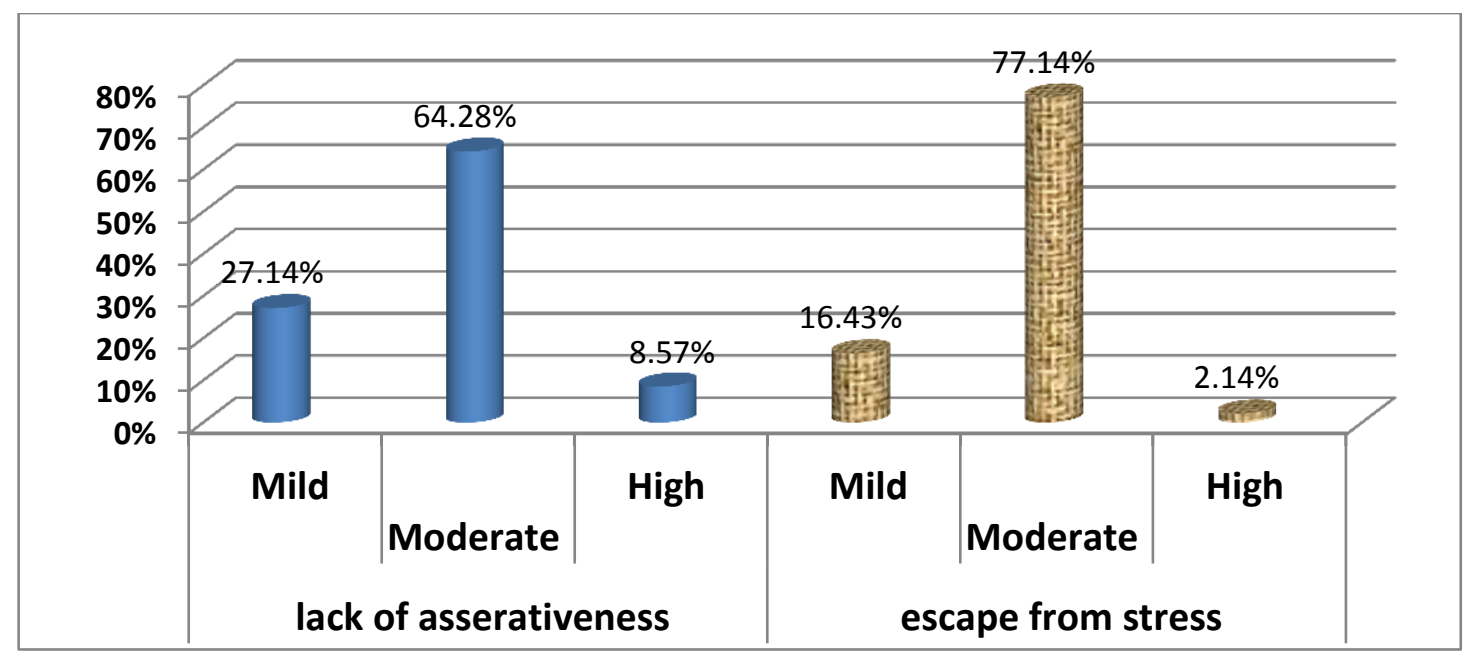

Figure (1): Frequency distribution of students according to their level of lack of assertiveness and escape from stress.

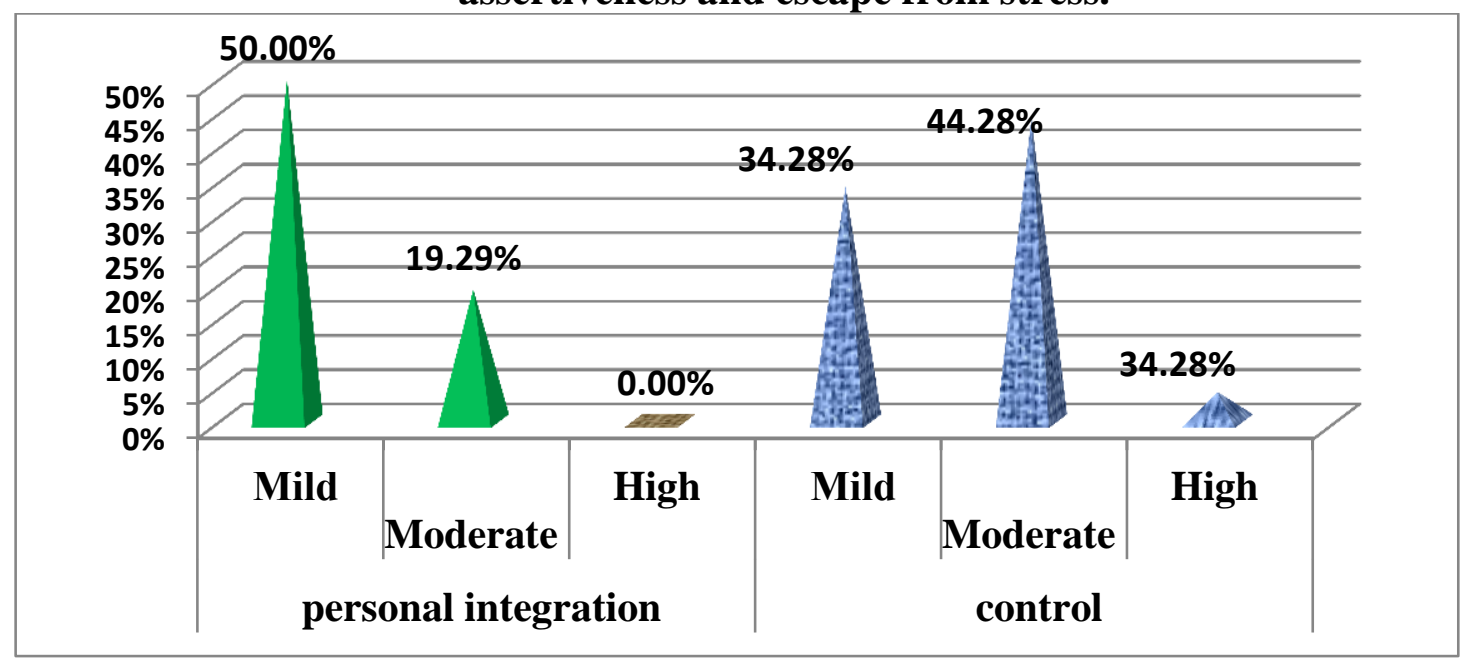

Figure (2): Frequency distribution of students according to their level of personal integration and control motives.

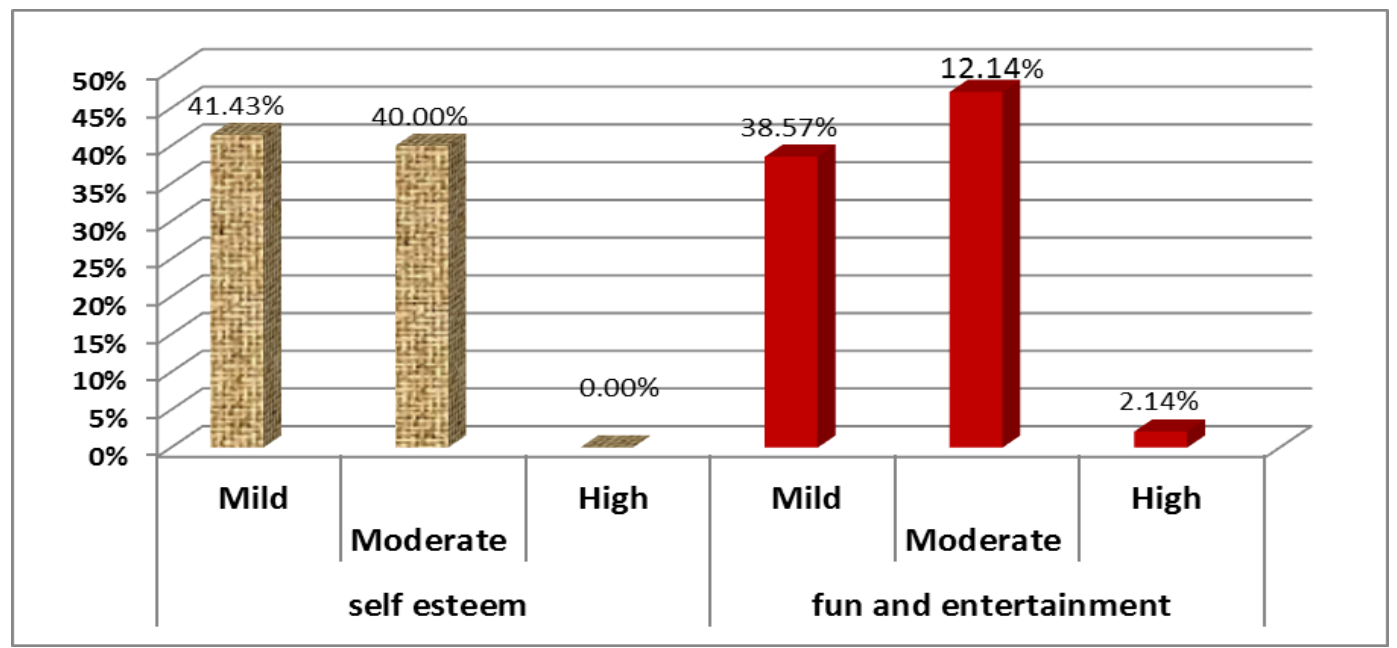

Figure (3): Frequency distribution of students according to their level of selfesteem and fun and entertainment motives 


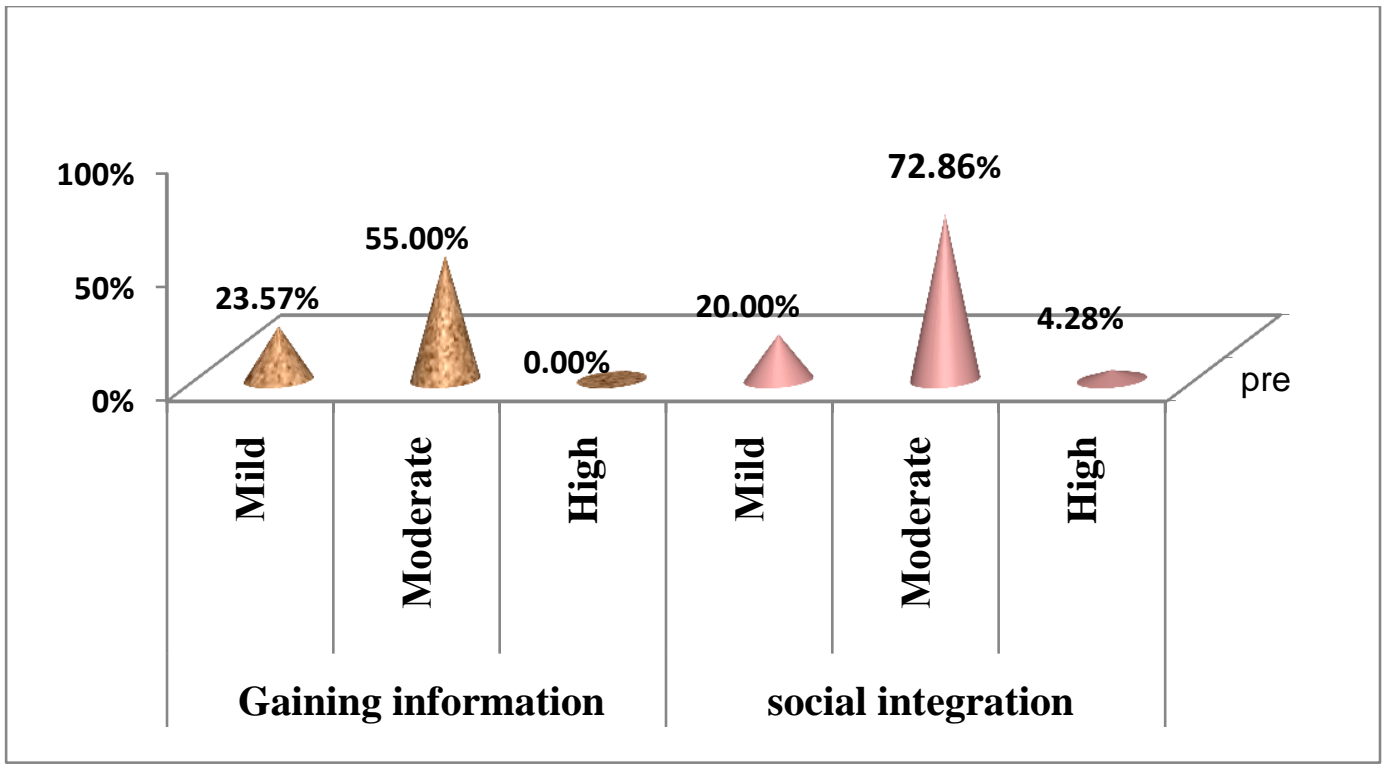

Figure (4): Frequency distribution of students according to their level of social integration and gaining information motives

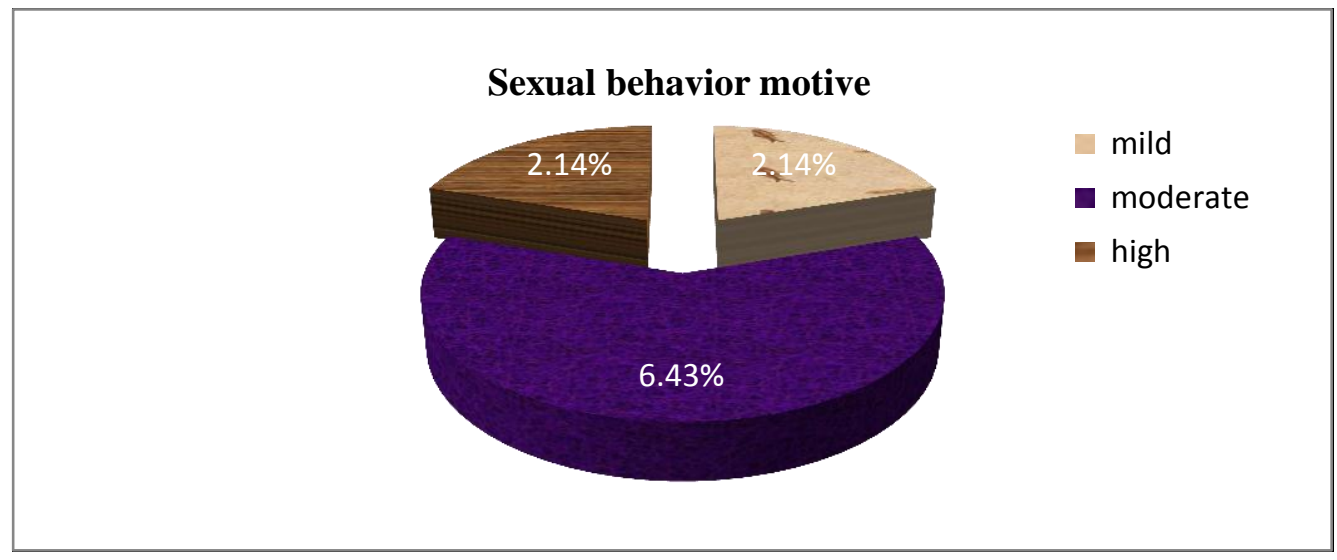

Figure (5): Frequency distribution of students according to their level of sexual behavior motives

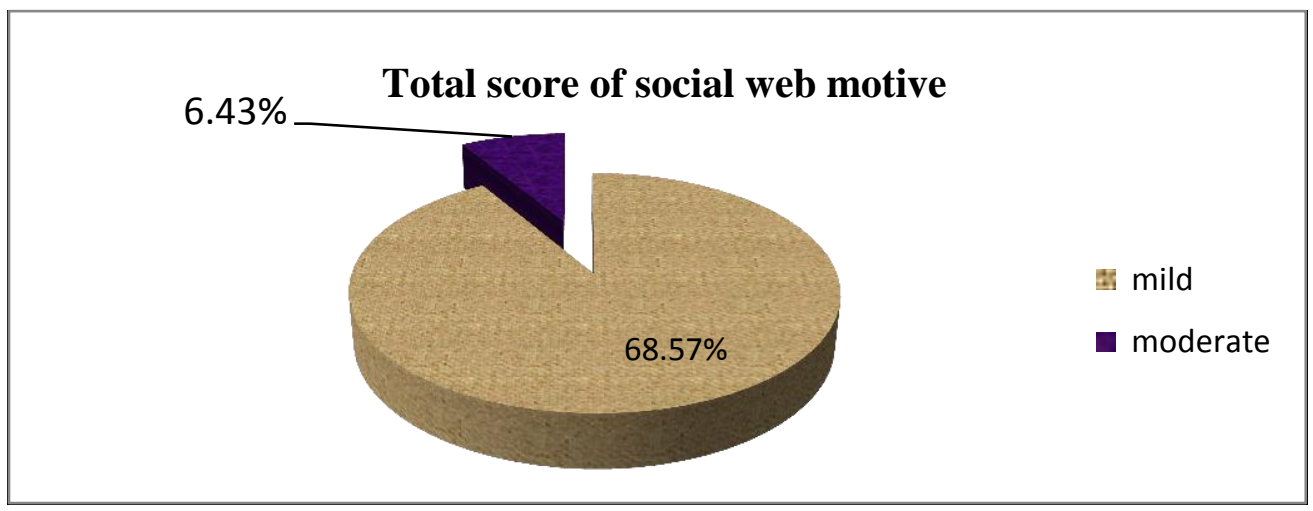

Figure (6): Frequency distribution of students according to their total score of social websites motive 
Table (1) Motivations for potential social websites addiction motives among males and females students

\begin{tabular}{|c|c|c|c|c|c|c|}
\hline \multirow{3}{*}{$\begin{array}{l}\text { Motivations for potential Social } \\
\text { websites addiction }\end{array}$} & \multicolumn{4}{|c|}{ Gender } & \multirow[t]{3}{*}{ t-test } & \multirow[t]{3}{*}{$\mathrm{P}$ value } \\
\hline & \multicolumn{2}{|c|}{ Males N=32 } & \multicolumn{2}{|c|}{ Females $N=108$} & & \\
\hline & Mean & SD & Mean & SD & & \\
\hline lack of assertiveness & 40.84 & 6.75 & 41.57 & 7.10 & $-.516-$ & $>0.05$ \\
\hline escape from stress & 19.09 & 1.20 & 18.18 & 3.36 & 1.497 & $>0.05$ \\
\hline Control & 11.53 & 3.26 & 13.43 & 3.27 & 2.892 & $<0.01 * *$ \\
\hline personal integration motive & 14.40 & 4.33 & 13.40 & 4.18 & 1.176 & $>0.05$ \\
\hline $\begin{array}{l}\text { ostentation and self-esteem } \\
\text { motive }\end{array}$ & 11.43 & 3.02 & 10.78 & 3.46 & .959 & $>0.05$ \\
\hline fun and entertainment motive & 12.78 & 2.39 & 12.06 & 3.56 & 1.068 & $>0.05$ \\
\hline gain information motive & 14.93 & 5.48 & 13.98 & 5.02 & .925 & $>0.05$ \\
\hline social integration motive & 22.71 & 4.73 & 22.39 & 4.11 & .374 & $>0.05$ \\
\hline Sex behavior motive & 4.96 & 2.23 & 3.11 & .660 & 7.636 & $<0.001 * *$ \\
\hline $\begin{array}{l}\text { Total score of social web sites } \\
\text { motives }\end{array}$ & 153.0 & 15.69 & 146.78 & 12.43 & 2.332 & $<0.05^{*}$ \\
\hline
\end{tabular}

Table (2) Correlation between motives for social websites use and potential social websites communication addiction among studied students (preltest)

\begin{tabular}{|l|c|c|}
\hline \multirow{2}{*}{\multicolumn{1}{c}{ Social websites motives }} & \multicolumn{2}{c|}{ potential social websites addiction } \\
\cline { 2 - 3 } & \multicolumn{2}{|c|}{ Pearson correlation co-efficient } \\
\cline { 2 - 3 } & $\mathbf{R}$ & p- value \\
\cline { 2 - 3 } & .293 & $<0.01^{* *}$ \\
\hline lack of assertiveness motive & .239 & $<0.01^{* *}$ \\
\hline escape from stress & .103 & $>0.05$ \\
\hline control motive & .152 & $>0.05$ \\
\hline personal integration motive & $-.118-$ & $>0.05$ \\
\hline ostentation and self-esteem & $-.106-$ & $>0.05$ \\
\hline Fun and entertainment & .010 & $>0.05$ \\
\hline gain information motive & .076 & $>0.05$ \\
\hline social integration motive & .047 & $<0.01 * *$ \\
\hline sexual behavior motive & .358 & \\
\hline Total motive Scoring system & & \\
\hline
\end{tabular}

\section{Discussion:}

In recent years, problematic social websites have emerged as a potential determinant of the health of adolescents and young adults. It tends to occur more regularly among younger than older users (Andreassen, Torsheim, Brunborg, and Pallesen 2012). During adolescence, a search for instant gratification and curiosity for new experiences converge with a feeling of invulnerability, making adolescents to be more exposed to risky behaviors as social websites addiction (Muñoz-Miralles, et al 2014). According to studies of pathological internet use, motives play an important role for predicted problematic use of social websites among university students (Hong, Huang, Lin, and Chiu 2014). Therefore this study aimed to assess potential social websites addiction motives among university students.

In relation to the first study question (What are the motives of social websites use among potential social websites addiction of university students?)

The current study revealed that the highest motives for social websites use were escape from stress, social integration, and lack of assertiveness respectively. This could be due to parenting style, perceived psychosocial 
stress, lack of emotional intelligence and using the social websites to reduce the negative affective states (anxiety) associated with social communication and also try to overcome the sense of isolation where students believe that the internet less risky as greater anonymity, more self-presentation control and a lower sense of public selfawareness than face to face communication.

The current study was congruent with Rahman, (2014) who conducted a research about "uses of social networking sites by public university students of Bangladesh" demonstrated that one-third respondents who are selected 'social interaction' as the highest social networking sites motives where nearly quarter of them use social networking site for assertiveness. This result was contradicted with Sali and Simsek (2014) who conducted a research about "the role of internet addiction and social media membership on university students psychological capital". They revealed that the need of assertiveness was the highest motive to use internet followed by social interaction.

For the second research question (Is there a difference between males and females students regarding social web sites motives?). There was an increase of the mean score of control as a motive for social websites use among females students than males students. This could be explained that females felt more control and more restrictions than males so; females used more social websites for the motive of control in order to feel freedom from authoritative persons.

This result contradicted with Shabir, Iqbal, and Safdar, (2014) who conducted a research about 'Demographics' Differences in Social Networking Sites Use: What Communication Motives Does it Gratify?". They reflected that males were significantly using social networking sites more than females to satisfy their interpersonal motive of control. Perhaps, this could be attributed to the misunderstanding of some question in their study.

Regarding sexual behavior as a motive for social websites use, there was an increase of the mean score of sexual behavior as a motive for social websites use among males students than females students. This could be due to in late adolescence sexual desire in males, limited religious awareness and lack of parents supervision. This result in the same line with Drouin and Miller, (2016) who mediator between internet addiction and engagement in risky online sexual behaviors". They found that mean score for sexual behavior motive among males students was higher than females students. This result also agreed with Soh, Teh, Hong, San Ong, and Charlton (2013) who conducted a research about "Exploring gender differences in Malaysian urban adolescent Internet usage". They declared that the mean score for sexual behavior motive among males students was statistically higher than females students.

Concerning the third research question (Is there a correlation between motives of social websites use and potential social websites addiction among university students?

The present study showed that there were a highly statistically significant correlations between potential social websites addiction and lack of assertiveness motive. This could be due to low assertiveness needs. Students who have low assertiveness presenting themselves as more competent and skillful, and able to master his $\backslash$ her life. Their belief that by using social websites they will feel safer, more efficient, more confident and relaxing than face to face relationship.

This result was supported by Evren, Dalbudak, Evren, \&Demirci,(2014) who conducted a research about "Online erotica usage as a studied "High risk of Internet addiction and its relationship with lifetime substance use, psychological and behavioral problems among 10th-grade adolescents". They declared that low levels of assertiveness are positive predictors of a problematic use of the web.

Similarly, Casale and Fioravanti, (2015) who conducted a research about "Satisfying needs through Social Networking Sites: A pathway towards Problematic Internet use for 
socially anxious people?. They reflected that the lower level of assertiveness, the higher the subjective importance attached to the social networking sites. On other hand, this result was contradicted with Ja, Sun, and Joo, (2016) who examined "The Relationship between social networking sites addiction tendency, self-assertiveness, and Interpersonal problems in College students. They stated that social networking sites addiction tendency was significantly negatively correlated with self-assertiveness.

Regarding escape from stress motives and potential social websites addiction, there was a highly statistically significant correlation between potential social websites addiction and escape from stress as social websites virtual community that publish many topics which provide euphoric feeling. These euphoric feelings act as temporally anesthesia that numbs the pain or distracts mind away from whatever is troubling to relieve stress.

This result was congruent with the result of Brooks, (2015) who conducted a research about "Does personal social media usage affect efficiency and well-being?". It represented that there was a positive correlation between social media usage and escape from stress. This result was also supported by Tompoulidis, and Tamika, (2015) who studied " relax and log on face book : examining students' use of face book to relieve academic stress through perceived social support ". They pointed out that statistical significant correlations were found between problematic use of social websites (face book) and escape from stress as a motive.

Additionally, these findings were in agreement with Guedes, Nardi, Guimarães, Machado and King, (2016) who assessed "Social networking, a new online addiction: a review of Facebook and other addiction disorders". They revealed that there was a positive correlation between social websites motive. This may due to social websites are addiction and escape from stress as an online motive.
Regarding the total score of social websites motives, the present study reflected that there was a highly statistically significant positive correlation between total social websites motive and potential social websites addiction. This could be due to social websites give the students many rewards as relaxation, escape from stress and selfassertiveness or gratification of different needs that can not satisfied in the real world. This can be explained according to Skinner's operant conditioning theory which person performs a behavior and gets either rewarded or punished for the behavior (Sue, 1994).

This point of view consistent with Wong, Yuen, and Li, (2014) who studied "A basic need theory approach to problematic Internet use and the mediating effect of psychological distress". They clarified that social websites have provide students with an immediate and easily accessible means to seek satisfaction and empowered them to control the way they present themselves regardless of their true identity or physical characteristics. It has thus become a very reinforcing stimulus.

Moreau, (2016) who conducted a research about "Contributions of Psychopathological and Interpersonal Variables to Problematic Facebook Use in Adolescents and Young Adults". They reported that pathological face book use scores were significantly related to motives. On other hand, these results were disagreed with Ibrahim, Mahmoud, and Mohammed, (2010) who studied "Internet Addiction and Motivation to use it and their relationship to social interaction with university students" they represented that there were no statistical significant correlations between internet use motive and internet addiction. The differences in current study might be related to the culture difference of Egyptian students and Saudi students

\section{Conclusion}

Based on the finding of this study and research question, it was concluded that the highest motives for social web sites use were escape from stress, social integration, and 
lack of assertiveness. There was an increase of the mean score of sexual behavior and total score of social websites motives among males students than females students. While there was an increase of the mean score of control motive for social web sites use among In addition, these results were in harmony with Chabrol, Laconi, Delfour, and females students than males students. There was a positive highly statistically significant correlation between potential social web sites communication addiction and both of lack of assertiveness, escape from stress and the total score of motive for social web sites use respectively.

\section{Recommendation}

A psycho educational program that aimed to increase parent insight about their children psychological, social need and problems during adolescence period and how to satisfy their needs must be developed.

Counseling program should be given to the university students to control the use of social websites and prevent falling into addiction public awareness about social websites addiction must be increased through use of media, religious counseling. Further researches that examine relationship between social websites addiction and self concept

\section{Reference}

Abdel-Sadek, H.(2013).Motives of university student internet use in Bahrain universities. Strategic vision Adults International journal High-Risk Behavior Addict. In Press(In Press):e32773. Published online 2016 September 27.2 doi: 10.5812/ijhrba.32773

Adnan, M., Shahzad, M., Husain,T., Andreassen S, Torsheim T, Brunborg S, \&Pallesen S. (2012). Development of a of Psychosocial Research on Cyberspace, 10(3), article 1. doi: $10.5817 / \mathrm{CP} 2016-3-2$

Brooks,S. (2015) Does personal social media usage affect efficiency and well- being?. Computers in Human Behavior. Volume 46 Issue C, May 2015 Pages 2637 doi $>10.1016 /$ j.chb.2014.12.053

Casale ,S, Fioravanti,G. (2015). Satisfying needs through Social Networking Sites: A pathway towards problematic Internet use Gratify? .International Journal of Social Work and Human Services Practice. Vol.2. No.5 Oct, 2014, pp. 184-194

Chabrol,H, Laconi, S, Delfour, M, and Moreau, A (2016) . Contributions of Psychopathological and Interpersonal Variables to Problematic Facebook Use in Adolescents in Adolescents and Young

Drouin, M., \& Miller, D. A. (2016). Online erotica usage as a mediator between internet addiction and engagement in risky online sexual behaviors. Cyberpsychology: Journal relationship to social interaction with university students . Scientific Journal of King Faisal University, 1 (11) .

Evren, C.,Dalbudak,E., Evren,B., \&Demirci, A.(2014). High risk of Internet addiction and its relationship with lifetime substance use, psychological and behavioral problems among 10th grade adolescents". Psychiatria Danubina, 2014; Vol. 26, No. 4, pp 330-339 Original paper (C) Medicinskanaklada - Zagreb, Croatia

Froget, J. R., Baghestan, A., G., Asfaranjan, Y. S. (2013) .A Uses and Gratification Facebook Addiction Scale. Psychological Report . 110(2):501-517. DOI 10.2466/02.09.18.PR0.110.2.501-517

Perspective on Social Media Usage and Online Marketing“, Middle-East Journal of Scientific Research, 15 (1), 134-145DOI: 10.5829/idosi.mejsr.2013.15.1.2127.

Guedes, E., Nardi, A.E., Guimarães, F.,M., Machado, S., King, A.,L. (2016).Social 
networking, a new online addiction: a review of Facebook and other addiction disorders. Medical Express 2016; 3(1):M160101. doi:

10.5935/MedicalExpress.2016.01.01

Hong, F., Huang D., Lin H., \&Chiu, S .(2014). Analysis of the psychological traits, Facebook usage, and Facebook addiction model of Taiwanese university students. Telematics and Informatics Journal. 2014;31:597-606. http://dx.doi.org/10.1016/j.tele.2014.01 .001

Ibrahim, S. , Mahmoud, Y. ,\& Mohammed, N. $\left.\left(Y_{\cdot}\right) \cdot\right)^{\prime}$. Internet Addiction and Motivation to use it and their relationship to social interaction with university students . Their study illustrated that no statistical significant correlation between internet use motive and internet addiction . Scientific Journal of King Faisal University, 1 (11).

Ja ,H ， Sun,O ， Joo.H . ( 2016).The Relationship between SNS addiction tendency, Self assertiveness, Interpersonal problems and in College students. Journal of the Korea Academia-Industrial cooperation Society. Vol. 17, No. 4 pp. 180-187, 2016.

http://dx.doi.org/10.5762/KAIS.2016.1

7.4.180 ISSN 1975-4701 / ISSN 2288$\underline{4688}$

Karahanna, E., Xu, S. X., \&Zhang , N. (2015). Psychological ownership motivation and use of social media. Journal of Marketing Theory and Practice, 23,(2), 185-207. ISSN 10696679, ZDB-ID King, D, L.; Delfabbro, P, H.; \&Griffiths, M,D. (2012).Clinical Interventions for Technology-Based Problems: Excessive Internet and Video Game Use, Journal of Cognitive Psychotherapy, Volume 26, Number 1, 2012, pp. 43-56(14).

DOI: https://doi.org/10.1891/08898391.26.1.43
Lin,Y. (2007). Effects of extrinsic and intrinsic motivation on employee knowledge sharing intentions. Journal of Information Science, 33(2), 135-149. doi:10.1177/0165551506068174

Makashvili,M. Ujmajuridze,B. Amirejibi,A. Kotetishvili,B. \&Barbakadze,S. (2013).Gender Difference in the Motivesfor the Use of Facebook. Asian Journal of Humanities and Social Studies (ISSN: 2321 - 2799) Volume 01- Issue 03, 130 - 135 . DOI: 10.13140/2.1.4946.7845

Mihara, S., Osaki,Y., Nakayama ,H., Sakuma,H., Ikeda,M., Itani, O., Kaneita, Y.,Kanda, H.,Ohida, T.,Higuc hi,S.(2016). Internet use and problematic Internet use among adolescents in Japan: A nationwide representative survey.

Medicine and Public Health. 3(5):12881297DOI:http://dx.doi.org/10.18203/23 94-6040.ijcmph20161400

Moreau A, Laconi S, Delfour M,\& Chabrol H.( 2015). Psychopathological profiles of adolescent and young adult problematic Facebook users. Computer in Human Behavior. 2015;44:649.doi.org/10.1016/j.chb.2014.11.045

Muñoz-Miralles R, Ortega-González R, Batalla-Martínez C, López-Morón MR, et al. (2014). Acceso y uso de nuevastecnologías entre los jóvenes de educaciónsecundaria, implicacionesensalud. Estudio JOITIC. Aten Primaria 2014;46(2):77-88.

Omar, B \&Subramanian,K.(2013). Addicted to Facebook: Examining the roles of personality characteristics, gratifications sought and Facebook exposure among youths. International Journal on Media \&Communications(JMC) Vol.1 No.1, March 2013, 46-65. DOI: 10.5176/2335-6618_1.1.6.

Pantic , I. (2014).Online Social Networking and Mental Health.Cyber psychology 
and Behavior and Social Networking . 2014 Oct 1; 17(10): 652-657. doi: $10.1089 /$ cyber.2014.0070

Rabie, H. (2003).Internet addiction on the basis of some variable .Derasat Nafseyah journal.Vol 13 (4).p.p 555580

Rahman,M. (2014) uses of social networking sites (SNSs) by public university students of Bangladesh . Global Media Journal: Pakistan Edition;Jun2014, Vol. 7 Issue 1, p46

Sali, J, \&Simsek,E. (2014). The Role of Internet Addiction and Social Media Membership on University Students' Psychological Capital CONTEMPORARY EDUCATIONAL TECHNOLOGY, 2014, 5(3), 239-256

Sevilla, C. (2012). Social Network Addiction and Your Next Case. Attorney Journal . Retrieved from http: //attorneyjournal.us/blog/2012/08/02/so cial-network-addiction-and-your-nextcase/

Shabir .G., ,Iqbal Y., Safdar, G.(2014).Demographics' Differences in Social Networking Sites Use: What Communication Motives Does it Gratify? .International Journal of Social Work and Human Services Practice . Vol.2. No.5 Oct, 2014, pp. 184-19

Shaheen, M.(2010). Motives of World Wide Web use Among Al-Quds Open University Students. Arab universities union journal, vol 56, December 2010, p.p 1-25

S Smock A. D., Ellison N. B., Lampe C. \&Wohn D. Y. (2011). Facebook as a toolkit: A uses and gratification approach to unbundling feature use. Computers in Human Behavior, 27, 2322-2329.

Soh, P. C-H., Teh, B.H., Hong, Y. H., Ong, T.S., \& Charlton, J. P. (2013, September 2). Exploring gender differences in Malaysian urban adolescent Internet usage. First Monday, 9. Retrieved from http://firstmonday.org/ojs/index.php/fm /article/view/4334/3745

Sue, D., Sue, D. , \& Sue, S. (1994). Understanding Abnormal Behavior.Boston: Houghton Mifflin

Ting-Peng, L., Efraim, T. (2012). Introduction to the special issue social commerce: a research framework for social commerce. International Journal of Electronic Commerce. 16, (2),5-14 .doi>10.2753/JEC1086-4415160201

Tompoulidis, $\mathrm{T}$.(2015). Relax and log on face book: examining students' use of face book to relieve academic stress through perceived social support.(2015). Theses and and Dissertations--Communication. Paper 36.

http://uknowledge.uky.edu/comm_etds/ $\underline{36}$

Wu, A. M. S., Cheng, V. I., Ku, L., \& Hung, E. P. W. (2013). Psychological risk factors of addiction to social networking among Chinese smartphone users. Journal of Behavioral Addictions, 2, 160-166.

Wong, T. Yuen, K. Li , W.( 2014).A basic need theory approach to problematic Internet use and the mediating effect of psychological distress .Frontiers in Psychology, 5 (2014), p. 156 